\title{
Indigenous Peoples and Development Processes: New Terrains of Struggle
}

\author{
MARIO BLASER, HARVEY A. FEIT \\ AND GLENN MCRAE
}

In the last three decades Indigenous peoples' struggles to keep control of their lives and lands have moved from being of concern only to themselves, and some specialists and specialized bureaucracies, to being issues of wide public awareness and debate in many sectors of society. Indigenous peoples' struggles are now carried on within complex transnational networks and alliances that traverse the boundaries between the state, markets and civil society, including the environmentalist and human rights movements. International forums such as the United Nations have become important sites in these networks, but major transnational organizations like the UN and the World Bank must themselves now have policies in place and access to expertise on Indigenous peoples in order to carry out many of their projects. Nearly every time the constitution of a nation-state is rewritten today, a major debate develops about how to include some form of recognition of Indigenous rights. Transnational corporations have to grapple with laws, norms and regulations that complicate their operations when these affect Indigenous peoples. These examples are but a few indications of the dramatically transformed terrains in which Indigenous peoples carry on their lives and their struggles today. Much has changed. But much has not changed.

This book provides the reader with a diverse series of analyses, strategic assessments, examples and reflections on Indigenous peoples' agency and struggles in the face of development projects carried out on these changing terrains. Many of the changes in the arenas in which Indigenous peoples carry on their struggles have been reshaped in these last decades by the initiatives of Indigenous peoples themselves. But much of the terrain has also been dramatically reshaped by others, through the changing roles of the nation-state and of NGOs, the growing importance of transnational corporations and global flows of capital, the expansion of media networks, and the 
rise of the environmentalist and human rights movements. These changes have altered Indigenous peoples' strategies of struggle to survive and to retain the autonomy they still exercise. We argue, however, that Indigenous peoples' agency and their alliances with wider movements themselves can have, and sometimes have had, transformative effects on the emergence of alternative structures of governance that are not rooted in globalizing development.

The chapters in this book present diverse insights into these developments. The editors have invited chapters from Indigenous leaders and Indigenous and non-Indigenous activists and scholars in the conviction that emerging issues can be best explored and understood by working through a set of differing perspectives and literary forms. The forms range from declarations, to histories, comparative analyses, theoretical explorations and analytical case studies, to practitioners' handbooks.

The 'mix' of authors is also an important feature of the book because their perspectives and experiences are rarely brought together. Rather they tend to be seen either as mutually exclusive (even antagonistic), or as representing diverse 'levels' on a scale of knowledge. We reject models that put local/ traditional knowledge and global/scientific knowledge on opposing extremes of a scale of accuracy and, therefore, authority. It is within a framework of openness to dialogue and emerging understandings that we seek to explore the themes of this book.

The theme of Indigenous peoples' agency in the context of the changing terrains in which development processes take place is explored in many of the chapters of this book as a counterpoint between 'life projects' and 'development projects'. The two introductory chapters serve the parallel aims of providing the contexts for the chapters that follow, and contributing to an emerging conceptual framework for understanding and acting in these new terrains. This introduction contextualizes the changes in the terrains of Indigenous action over recent decades, and provides a preview of each chapter in the volume. The other introductory chapter, by Mario Blaser, sets out the idea and practice of Indigenous life projects as a key to understanding and rethinking Indigenous agency in the midst of these changing contexts. It explores how Indigenous projects are linked to those terrains but also how Indigenous life projects differ from the dominant and more common ideas and practices of development and development projects. That chapter also provides an account of the structure of the volume in terms of its thematic sections.

Our sense as editors is that many readers of this volume will come to it with familiarity with one or more of the areas of these changes. But because we think that there has been only limited overlap between the literatures and venues devoted to Indigenous issues and those focused on development, we assume that many readers will not be familiar with the 
recent developments in all of the fields involved, and that most will not be familiar with the growing connections between them. This introduction was, therefore, conceived of as an overview of recent trends in, and the interconnections among, the areas of Indigenous rights, human rights, sustainable development, civil society and globalization. Our aim is not to review each area comprehensively, but to draw out how the changes in each of these areas impact and are impacted by Indigenous peoples. Indeed, we think that Indigenous peoples and issues have become key links among these terrains of knowledge and struggle.

\section{Terrains of Subordination and Survival}

Indigenous lives and life projects have never been pursued in a vacuum; they can only be pursued amidst other projects. If the relations between different projects were more or less symmetrical, the broad cultural values and the visions of both Indigenous peoples and developers would each find some point of mutual accommodation. As a few chapters in this volume show, when conditions of a relative balance of power occurred the treaties made between Indigenous peoples and newcomers have embodied the cultural underpinnings of both groups, as in the Two-Row Wampum discussed by Deborah McGregor and by Mary Arquette, Maxine Cole and the Akwesasne Task Force on the Environment.

Yet once the newcomers secured their dominion over Indigenous peoples - by resettlement with the aid of depredations caused by the spread of disease, military conquest, or incremental dispossession - they refused to recognize the latter's conceptions of right and the pursuit of their life projects, justifying this on the basis that Indigenous societies and cultures were primitive and undeveloped (Asch 2000). In this new situation of asymmetry, the colonizers have repeatedly imposed their cultural forms on relations with Indigenous peoples. Thus, under the 'custody' of the nation-states, Indigenous lands and resources, and even their children, have been susceptible to seizure either in the name of the greater good, for an abstract 'all', or for their own presumed benefit. These actions assume the colonizers' conceptions of the correct relationships that must prevail among humans, as individuals and groups, and between human and non-human entities, or roughly what is called 'nature'.

In the international system of sovereign states those Indigenous spokespersons who have again and again called attention to these abuses have gone mostly unheard (Wilmer I993: 2-3). Further, even when abuses were attended to, the basic storyline of development was not doubted. As the International Labor Organization Convention 107 of 1957 expressed it: 
Considering that there exist in various independent countries indigenous and other tribal and semi-tribal populations which are not yet integrated into the national community and whose social, economic or cultural situation hinders them from benefiting fully from the rights and advantages enjoyed by other elements of the population ... [g]overnments shall have the primary responsibility for developing co-ordinated and systematic action for the protection of the populations concerned and their progressive integration into the life of their respective countries [although] recourse to force or coercion as a means of promoting the integration of these populations into the national community shall be excluded. (ILO I957)

Thus Indigenous peoples continually find themselves subordinated within the nation-state and international system. This implies that, for the most part, their struggles to pursue their own life projects take place in a field dominated by Western 'cultural underpinnings', including the central idea of development (see Stavenhagen I996; Tully 2000).

In contrast, the visions embodied by Indigenous life projects entail a relationship between equals and an end to the subordination of Indigenous peoples. Thus, attention to the field of power relations in which they operate is among the central considerations of life projects. This attention to relationships and power informs the strategies through which Indigenous organizations struggle to end the subordination of their life projects and to pursue their unhindered realization. Central to their strategies has been the mobilization of Indigenous peoples for recognition of their rights. When we speak of rights, we are speaking of more than legal issues. We are talking more broadly of the life projects that embody visions of the world and the future, and of the inherent right to pursue one's own life.

As a consequence of the subordination of Indigenous peoples, their life projects have had to be furthered through the cracks left open, by unexpected events and the passage of time, in the oppressors' own discourses and legal expressions of rights. By having to speak the 'language' of the dominant group, the broad cultural underpinnings of Indigenous peoples' struggles have often been obscured, and their political significance has gone unaddressed by most analysts. This volume is part of a growing and diverse literature that seeks to reduce that omission.

From the 1960s onwards, and in connection with both the civil rights and decolonization struggles occurring around the world, subordinated groups, including Indigenous peoples, began to call more effective attention to the contradictions between the standards of human rights proclaimed by nationstates and international standards, and the actual way in which these were imposed on or ignored for Indigenous peoples (see Brysk 2000; Messer I993; Niezen 2003; Wilmer I993; Wright 1988). In the process they contributed to the erosion among nation-state authorities, and the public more generally, of 
unselfconscious confidence in dominant Western values, including the ideas of development.

In order to provide a background picture of how these transformations took place, what new political terrains they have shaped, and how Indigenous peoples pursue their life projects in them, we will examine several areas on which key changes have occurred. In the next section of this chapter we provide a brief overview of the processes through which Indigenous rights emerged in the context of development and the connections of these processes with environmental issues. In the following section we focus on the contemporary political terrains that have been partly shaped by these processes and discuss Indigenous peoples' organizational adaptations and strategies to pursue their life projects in the new terrains.

In reviewing the changes of recent decades we also set out to build some additional bridges between the domains of Indigenous rights as a specialization and critical development work, because these connections have often not been considered central to social analysis and action.

\section{Indigenous Rights and Development}

As indicated by the fragment from ILO Convention 107, the broader agenda of development included human rights to the extent that 'integration' of Indigenous peoples was supposedly aimed, in part, at extending to them some socio-economic human rights, or 'second-generation rights' (Messer 1993: 222). However, in pointing out that force had to be excluded as an instrument of integration, the convention underscored the contradiction between the goal of recognizing human rights and the way in which development was often being delivered.

When, in the late 1960s and early 1970s, the international human rights network began to take shape, some organizations - like the Anti-Slavery Society, the International Work Group on Indigenous Affairs (IWGIA), Survival International and Cultural Survival - focused specifically on the abuses committed against Indigenous peoples (see Martinez Cobo I986; Wilmer I993: I4I). These organizations were at odds with dominant ideas in governmental circles because they asserted that respect for cultural differences was a viable alternative to integrationist development. Over time they developed active collaborations with ongoing efforts by Indigenous peoples to organize and make their voices heard in international arenas. For Indigenous peoples, this was a means to improve their situation in the national contexts where they lived (see Bodley 1988; Sanders 1977; Davis 1977; Wright 1988). 
In the I970s the proliferation of Indigenous advocacy and Indigenous organizations closely matched the internal expansion of many nation-states as they initiated grand schemes of development affecting resources and Indigenous peoples in 'peripheral areas', including, among others, agrarian reform, agricultural colonization, green revolution schemes, road building, dams, mining, and oil exploration and production (Sanders 1973; Wilmer I993).

Indigenous peoples in Latin America, for example, responded to the developmentalist wave of the 1960 s and 1970 s by trying to stop it, or trying to direct some of its policies and programmes to their own benefit. The last strategy was used particularly in the context of agrarian reforms initiated by nation-states, and it involved the reshaping of previous relationships between Indigenous and non-Indigenous organizations and movements in each national context. In the Andean regions of countries like Bolivia, Ecuador and Peru, as well as in Guatemala and Mexico, Indigenous peoples created unions, political parties or cooperatives that, until the I980s, did not articulate their demands in terms of their Indigenous identity; rather they tended to identify themselves as peasant organizations (see Yashar 1998; Albó 1999). In contrast, the organizations that emerged to challenge the threats of encroachment and destruction posed by the expansion of the states and markets into areas that had remained mostly outside their reach adopted a more decidedly international stance, without disregarding national alliances but stressing their ethnic identity (Ramos 1998; Maybury Lewis 1999; Brysk 2000).

The early organizations emerged with the support of non-Indigenous institutions, particularly sectors of the Catholic Church influenced by liberation theology. As Indigenous organizations grew they developed connections with each other. They obtained leverage through the international human rights network, whose main strategy consisted of lobbying donor countries and multilateral organizations to make development aid conditional upon the recipient countries' record of human rights (Sanders 1977: 25-6; Tomasevski 1993: 84-5; Keck and Sikkink 1998: 102-3). However, this support was not universal, and, in contrast to those organizations which specialized in Indigenous issues, the wider human rights network did not see development aimed at integrating Indigenous peoples into the national society as a human rights violation. Thus the ability of Indigenous organizations to call on human rights groups to further Indigenous life projects was limited (Brysk 1994, 1996). As long as a 'developing' state followed the model of the developed countries and avoided the most flagrant violations of human rights in executing its projects, its integrationist development agenda remained legitimate.

Through the I980s Indigenous movements in Latin America actively participated in the wider processes of democratization that swept through 
the region (see Diaz Polanco 1997; Van Cott 1994; Ramos 1998; Horst I998; Warren 1998). Thus, the idea of respect for Indigenous peoples' cultural differences began to expand, at least as rhetoric, into the policymaking of development donors, governments, international institutions and even markets (see Assies et al. 2000; Brysk 2000; Van Cott 2000). In the 1990s, several Latin American countries began state reforms. Although these reforms took shape in a wider context informed by neoliberal agendas such as the liberalization of trade, downsizing of the state, and decentralization of its operations, they opened the door for groups with specific interests to fight for inclusion in this process. This was the case with Indigenous rights, which were incorporated in a number of new national constitutions that emerged from these processes of state reform (see Yashar 1998; Van Cott 2000; Sieder 2002).

In North America the expansion of resource and social development projects in the I960s and I970s also gave impetus to rapid Indigenous mobilizations, led in some cases by Indigenous peoples in formerly remote or isolated areas who were now experiencing development projects on a new scale. In the post-Second World War boom years the growing affluence of significant sectors of North American societies led to a growing awareness of poverty, the failures of development and civil rights abuses for other sectors of the population and in some regions of the nation. The growing demands, and wider public awareness and support, for redressing these 'inequalities' focused on integrationist projects for economic development of black and urban poor communities and Indigenous urban and rural people. This wave of organizing and public support, and government efforts at co-optation, facilitated the emergence of new Indigenous organizations at regional and national levels in each country as governments needed and sought representatives with whom to consult on the development of policies and programmes for Indigenous peoples. This entire process was still envisaged within the framework of externally driven development projects. The new Indigenous organizations that survived from this period developed into more autonomous voices and actors, although for a long time some saw such development as the only avenue of escape from the history of colonial administration.

In the I970s and 1980 s breakthroughs in the national legal recognition of Indigenous rights transformed the arenas of action in the USA, Canada and Australia. Court cases brought by Indigenous peoples gained new recognition for Aboriginal rights based in part on legal anomalies and residues of the history of their recognition, and in part on challenging the courts to reread the provisions in earlier treaties both as binding documents and in the light of ideas of the period and testimonies about how they were presented, explained and negotiated with Indigenous signatories. In this light, legal provisions often affirmed and allocated access to resources, lands and aspects of self-government and sovereignty, and courts recognized that in new 
ways (Asch 1997; Harring 2002). In the USA and Canada treaty recognition expanded, and emerged alongside the first legal recognitions in Canada and Australia that Indigenous rights still existed generally over the land where they had not been dealt with by treaty. Once these legal changes began, they were also given impetus by the massive capital now being mobilized for resource developments in isolated regions of the continent and the corporate and investor needs that there be legal clarity and assurances about rights to lands and resources to protect investments.

These developments dramatically shifted attention from socio-economic deprivation to legal rights and governance claims, which had the effect of making Indigenous issues into questions of national importance for the first time in a century or more in these countries. The legal changes decisively moved the focus to the problems of recognizing plurality (Asch 1984; Tully I995). These processes were paralleled by opportunities for Indigenous action under legislation assuring public involvement in environmental decisionmaking and the recognition of religious rights and freedoms.

The subsequent three decades have seen a plethora of legal developments, and setbacks, and growing and challenging assertions from Indigenous peoples that recognition of their rights does not mean recognition defined solely by the structures of colonial and national law, but of their own systems of customary law, governance, tenure and resource uses, and 'ways of life' or life projects (Lyons and Mohawk I992; Alfred I999; Harring 2002). In recent years, the continuing resource developments on Indigenous lands despite recognitions of legal rights, the growing conservatism and declining sympathies of a public that itself feels less secure in its affluence under neoliberal changes, and the continuing gap between the living standards of Indigenous peoples and other North Americans have led to a new urgency and recognition by many Indigenous communities that they need to participate in some forms of development (RCAP I996). The patterns of that participation have, as yet, not become clear (but see Russell (Chapter 8), Coon Come (Chapter 9), Craik (Chapter I0) and Scott (Chapter 7) in this volume for exploratory initiatives).

Indigenous claims have in general been increasingly expressed through international initiatives and alliances aimed at pressuring national governments; through the development of Indigenous rights forums and draft conventions; through environmental alliances; and through a burgeoning public recognition of Indigenous arts and media. The latter have become a successful sector of North American, European and Australian consumer culture, albeit with mixed effects (Conklin and Graham I995; Niezen 2003; Povinelli I 993, 2002).

Until the late $198 \mathrm{os}$, the most common response of multilateral development institutions and states to the contradictions between the growing 
pressures on them to uphold the rights of Indigenous peoples and the way in which development was carried out was the promotion of measures to mitigate the impacts produced by development (see Tomasevski I993: 67-8; Davis 1993; Deruyttere 1997; Burger 1998; Swepston 1998; Kreimer 1998; Sanders 1998). However, through the I970s the contradiction was increasingly clear, and this helped to open a crack in the so-far solid confidence that progress justified almost everything. This crack was widened with the consolidation in the 1980 os of the transnational environmentalist movement. With this, the idea that Indigenous peoples have the right to sustain their own life projects received new impetus.

\section{Ecological Differences}

We will discuss here neither the antecedents nor the details of the last wave of environmentalism that arose almost parallel with the international Indigenous movement and that was consolidated during the $1980 \mathrm{os}^{2}$ Our focus is on how development was transformed by this movement and, in turn, how this transformation affected the struggles of Indigenous peoples to further their life projects.

By the mid-I980s, when environmental activism was booming, it was clear that a new form of relation between developmental and environmental concerns had to be worked out. Different positions about what the new relation should be were proliferating and becoming more visible as different organizations, institutions and movements established connections with each other. Just to mention a few, these positions included radical environmentalism arguing for the total subordination of human activity to natural cycles; environmentaljustice movements and eco-socialists putting social inequalities at the top of the environmental agenda; peasants and Indigenous peoples mobilized against the privatization of their lands and resources; and ecological modernization advocating technical fixes for environmental problems (see Taylor I995; Painter and Durham 1995; Hajer I995; Collinson 1997; Esteva and Prakash 1998; Parajuli 1998). The result of these debates was the incorporation of environmental concerns into developmental agendas, and of developmental concerns into environmental agendas, by way of the concept of 'sustainable development'. Popularized by the report Our Common Future (World Commission on the Environment and Development [WCED] 1987), the ambiguities in the concept of sustainable development made it a useful tool for those pursuing agendas across interfaces connecting organizations and movements with radically different views (Ekins 1993; Worster 1993; Adams 1995).

Sustainable development and its environmental underpinnings contributed to widening the cracks through which Indigenous peoples' life projects could 
be pursued. Moreover, it strengthened Indigenous peoples' leverage in their dealing with development agendas promoted by state and markets. In the midst of heightened 'environmental awareness' (Lanthier and Olivier 1999), the trope of 'endangered forest, endangered people'3 provided Indigenous peoples and their advocates not only with a way to frame integrationist development as inherently abusive of their universal human rights, but also with a platform to build the argument that Indigenous societies and cultures are a critical resource in the global search for sustainability because of their traditional environmental knowledge (TEK). Thus, as the sustainable use of the environment became the stated goal of several development institutions, Indigenous peoples came to be seen as worth preserving along with nature. With a synergistic effect, these developments were paralleled by the Indigenous peoples' participation in the democratization movements that, as mentioned before, swept through Latin America during the 1980s.

One could say that with the UN's Agenda 21, which provided the framework within which the nation-states should pursue the sustainable development of their societies into the twenty-first century, a reconfigured perception of Indigenous peoples was officially sanctioned by governments and development institutions. In this perspective 'indigenous peoples are given central focus because of rather than in spite of their cultural differences' (Ellen and Harris 2000: 13, stress in the original; see also Conklin 1997). For example, Chapter 26 of Agenda 21 states that,

In view of the interrelationship between the natural environment and its sustainable development and the cultural, social, economic and physical well-being of indigenous people, national and international efforts to implement environmentally sound and sustainable development should recognize, accommodate, promote and strengthen the role of indigenous people and their communities. (UNCED 1992)

The focus on the environment is important to Indigenous peoples in part because it provides a narrative anchor by which their concerns with survival can be articulated with non-Indigenous peoples' concerns for survival. In many cases development projects promoted by states and corporations on Indigenous territories have important environmental impacts that reach well beyond local settings. Thus, the potential exists for Indigenous peoples to gather support on the basis that the threat to their territories and survival constitutes a threat or a loss to people located elsewhere and a responsibility on the part of those whose lifestyles would benefit from the resources being extracted. The connections between these concerns are often constructed through alliances between Indigenous organizations and urban-based NGOs which may translate Indigenous concerns into a language of environmentalist symbols that are meaningful for the public whose support is vital. The problem is that these translations often involve important distortions of 
Indigenous perspectives that eventually resurface and often create feelings of betrayal between former allies.

Guha and Martinez-Alier (I997) point out what they call the fundamental difference between 'the ecology of affluence and the environmentalism of the poor'. The dominant thrust of environmental movements and NGOs among relatively affluent urbanites has been the preservation of wilderness and protection and respect for other species. By contrast, the environmentalism of peasants and Indigenous peoples is often wrapped up in the problems of subsistence (see also Taylor 1995; Esteva and Prakash 1998). Because of the subordinated positions in which Indigenous peoples find themselves, it is usual for this second form of environmental concern to be translated into the first form. This pattern also occurs among those non-Indigenous allies who were more inclined to accept the idea of sustainable development than environmental preservation, but who nevertheless retain for themselves the authority to define what it means. Such alliances are bound to end in disappointment, for they disregard the fact that Indigenous communities oppose large-scale developments and programmes that imply the erosion or takeover of their subsistence base and territories, yet at the same time they seek to promote their own life projects. This usually entails resource-use projects that Indigenous communities envisage will improve the economic and social conditions under which they live but that can be entirely unacceptable to former allies.

\section{Sustainable Development, Civil Society and Globalization}

The role of Indigenous peoples and the environment is not the only feature that has changed in the new official visions of 'sustainable development'. Now organizations of civil society and not state governments are seen as the most appropriate instruments to achieve the sustainability of an economic development whose main motor is the market (see Peet and Watts 1996). In relation to the previous view of development, this refurbished version shows important differences. Development is no longer the responsibility of the state; rather, the state sets the wider framework, the market must be its motor, and civil society would give it direction ( $R$ ist 1997: 223-6). These transformations of development discourses and practices are part and parcel of wider processes often referred to as globalization. These processes, characterized by the increasing circulation of peoples, ideas and commodities, prompt the emergence of organizational forms that are intended to control, adapt and tap into those circulations. Thus, many of the functions held by the nation-state are transferred upwards to supranational institutions and common markets through economic and political integration, downwards to regions and com- 
munities through political and administrative decentralization, and sideways to NGOs and the private sector through 'democratization' and privatization. As Rose (1996) points out, the state is increasingly 'de-governmentalized' and the practices of government 'de-statized'. The significance of these changes goes beyond any diminution in the role of the state, or shifts in the balance of power between the state, on the one hand, and market and civil society, on the other. Rather the meaning of these changes is that the boundaries of these domains get increasingly blurred (Alvarez et al. 1998; Wood 1997; Pearce I997; Barry et al. I996).

In the discourses of development this blurring of boundaries is underplayed, or rather it is interpreted as democratization because of the expansion of civil society. This view serves very well the development strategy that has become dominant in governmental and multilateral institutions. This strategy, based on neoliberal economics and liberal political theory (Edwards and Hulme 1996b), assigns to the state the role of a legislator and guarantor of the rules that allow the market to operate unhindered on a transnational and global scale. The assigned role for the market is to generate the wealth with which development can be built. The task of making development 'human' (see UNDP 1990: 10) - that is, to input other values than economic efficiency - has been increasingly assigned to organizations from civil society, or NGOs. This is because NGOs are perceived as well suited to provide the services that states abandon as structural adjustment advances, and to set limits to state abuse and inefficiency and provide a vehicle for more democratic participation through civil society (Hudock 1999; Eade 2000; Edwards and Hulme I996a; Hulme and Edwards 1997).

The centrality that NGOs have acquired in development agendas has been shaped not only by forces coming from governmental and multilateral development institutions but also by pressures from grassroots movements resisting or trying to modify the development agendas promoted by states and markets. Often there is a coalescing into formal organizations, including NGOs of distinct social movements, such as those that resent the human, social and environmental consequences of development agendas, those that seek to incorporate their concerns into the development agendas, and those that want to further alternative life projects (see Geddicks 1993; Taylor 1995; Collinson 1997; Esteva and Prakash 1998). In searching for leverage to accomplish their purposes, NGOs have tended to establish links with each other and with governmental and multilateral institutions (see Keck and Sikkink 1998; Fox and Brown 1998; Alvarez et al. 1998).

In turn, the development industry and governments in many countries have realized that they cannot negotiate with the vast number of local communities and groups. Thus, since the late I980s, they have begun to rely on NGOs to communicate, consult and implement programmes. In 
this context, most organizations of the so-called civil society have ended up performing hybrid functions, serving multiple purposes and shaping, along with state and market organizations, a complex transnational network through which the life projects of Indigenous and other groups and the different agendas of development are struggled over (see Fisher I997; Bellier and Legros 200I).

Indigenous peoples have had to keep pace with these complex changes. Thus they make use of a wide spectrum of strategies and organizational possibilities adapted to the evolving terrain in which their struggles take place. A detailed description of these organizational forms and strategies would exceed the scope of the volume, yet we think it useful to highlight some general patterns that can be extracted from the pertinent literature, specially those patterns that are relevant to understanding the cases discussed here. ${ }^{4}$

\section{Indigenous and Non-Indigenous Organizations}

To understand the organizational forms adopted by Indigenous peoples' movements, it helps to consider the relationships between these movements and the degree of control and input that Indigenous peoples have in the political and judicial processes that affect them - in other words, to what extent they can further their claims through political parties, unions and/or other organizational forms with direct access to decision-making processes within the state and/or by recourse to a relatively independent judicial system. ${ }^{5}$ Another illuminating dimension is the relationship between organizational forms and the demographic weight that Indigenous peoples have in the total population of a nation-state. Focusing on these dimensions we suggest that:

- In national contexts where Indigenous movements have relatively high levels of control and input in the political process, and their demographic weight is nationally or regionally important, Indigenous concerns can achieve expression in practically the whole spectrum of organizational forms from political parties to NGOs, and from local forms of government to unions. This obtains in varying degrees, but the paradigmatic case is Bolivia, where in 1993 the president and vice-president of the Republic emerged from a coalition of Indigenous movements and a political party. To a lesser extent Ecuador and some regions in Mexico fit this scenario.

- Where high demographic weight is associated with low control and input to the political and judiciary process, it usually occurs because participation is blocked by the use or threat of violence. These are highly explosive con- 
texts where armed struggles are a likely occurrence with the consequent formation of guerrilla-type organizations, although this does not mean that other forms of organizations will not be present. The paradigmatic cases here are Guatemala and Chiapas in Mexico.

- In contexts where control and input are relatively high but demographic weight is low, organizational forms usually include, with varying levels of sovereignty and autonomy, some state-recognized form of tribal government, or Indigenous governments that exercise sovereignty over restricted territories, or de facto ethnically controlled regional governments within a national structure. The Kuna in Panama, the Miskito in Nicaragua, the larger self-governing tribes in the USA and the Inuit of Nunavut in Canada are examples of these possibilities.

- In contexts in which Indigenous movements have relatively low control and input and little demographic weight, what we commonly find is the presence of NGOs that may perform governmental functions in parallel or conjunction with established local Indigenous sources of authority.

Most cases in this volume fall into the last two categories. In these categories, complex forms of organization can develop and also be transformed into other types. Usually the invasion of governmental authority and development projects into local settings requires the creation of a forum that the interlopers can negotiate with and understand. Thus where local systems of organization cannot provide such forums, or established local governments are not recognized as such by dominant institutions, the state or private sector takes over essential functions such as the administration of justice and control over common resources, among others. This has happened to most Indigenous peoples throughout the world in varying degrees.

However, Indigenous peoples have often succeeded in creating NGOs that provide both an institutional interface with outside pressures and a forum in which the language of the state and development industry can be translated for the local community, and vice versa. Now, these forms of organization can coexist with already established or 'traditional' sources of authority and government, or they can eventually evolve into such. In any case, these organizations may administer community funds, start businesses, serve as a forum for negotiations among the communities' members themselves and with provincial and national governments, carry out local governance functions, and engage in international diplomacy and litigation.

Local NGOs can provide a deliberative buffer between communities and outsiders (developers or other NGOs and social movements), often to the frustration of non-Indigenous NGOs and governmental units seeking quick decisions. This intermediary position opens up great opportunity to sustain and protect local processes, but also to create misinterpretations or even 
abuse. This is ingrained in the nature of local NGOs, for they are generally controlled by a small group of people who act as representatives of a whole community, a community which might not operate according to the expectations of state representative politics. In addition, to the extent that these organizations are not clearly established as legitimate authorities, they are vulnerable to attacks by interested external parties who may claim that they do not represent the interests of the communities and therefore disregard them as valid political interlocutors. This is a common tactic by governments and private interests when the agendas put forward by local organizations collide with their interests.

In summary, Indigenous organizations could be analysed as part of civil society, yet many of them take on governance functions. In many cases they even become entrepreneurial, taking on functions usually relegated to the marketplace. Moreover, Indigenous administrative structures and service organizations are, on occasion, tied to state structures for funding and legal legitimacy, which in turn makes them partly accountable to the state. Nevertheless, they may also be held accountable to other sources of authority deriving from established 'traditional' institutions, such as hereditary chieftaincies or elders, or in relation to locally held moral values and notions of legitimacy. Thus, Indigenous organizations are inside and outside both civil society and the state and markets. But this positioning, as several chapters show, fits quite well with contemporary processes that make it difficult to sustain the distinction between civil society, state and market.

\section{Indigenous and Non-Indigenous Strategies}

There is also a relationship between the degree of control and input that Indigenous peoples have in a nation-state's political and judicial processes and the dominant orientation that emerges in patterns of alliance-making, lobbying and support gathering. In varying degrees, the greater the control and input, the more the strategic orientation of Indigenous movements is inward towards the national context. In the Americas, inward orientations are observed mostly in contexts in which Indigenous peoples' participation in the political process is not severely or specifically blocked, or where some degree of sovereignty and self-determination, recognized through treaty rights and other binding agreements, are enforced or can be plausibly contested on grounds of non-enforcement. In North America a dominant inward strategic orientation has also been connected to the modest effect that pressures and lobbying via external third parties can have in so-called First World states' political and judiciary processes, although it can be important in specific instances. 
The 'boomerang strategy' (Keck and Sikkink 1998: I2-I3) of using international political arenas to influence national decision-making is most common in contexts where control and input by Indigenous peoples in the political and judiciary process are more restricted and where armed struggle is clearly not a viable option. ${ }^{6}$ The boomerang strategy can be aimed at stopping or modifying particular development projects or promoting wider policy and legal changes to attain Indigenous peoples' rights. However, as we hinted above, Third World states are usually more vulnerable than First World states to these kinds of strategies because in most cases they need the latter's political and financial support (also channelled through multilateral financial institutions) to advance development projects. These First World states, in turn, often do not have too much to lose, and sometimes have something to gain, by submitting to the demands of environmental and human rights lobbying groups, since they can claim credit for trying to improve conditions in the Third World.

Private corporations undertaking mega-development projects in Third or First World countries are even more shielded than First World states against this strategy, since private financing institutions do not necessarily subscribe to or enforce the norms officially accepted by public institutions regarding Indigenous peoples' rights. ${ }^{7}$ Moreover, as Johnston and Garcia-Downing point out in this volume (Chapter 13), lack of accountability becomes the norm as the privatization of development financing expands.

A corollary of this is that Indigenous peoples facing mega-development projects are left in a very weakened position - they can count less and less on the boomerang strategy and often do not have recourse to a relatively independent judicial system. But even if a relatively independent judicial system exists, it is an alternative only to the extent that Indigenous peoples have the economic means to make use of it. And even in that case, the legal alternative is besieged by traps and counterproductive results for Indigenous movements. All of this indicates the need to follow a multi-pronged strategy of lobbying, alliance making, appealing to courts, and public campaigns.

Yet the feasibility of a multi-pronged strategy that includes alliances with other social movements and NGOs as well as public campaigns is highly dependent on the existence of clearly delimited and visible rallying points of common interest. Such can be the case in the impending construction of a dam or mine (see Coon Come, Craik, and Gedicks and Grossman, Chapters 9, Io and II in this volume) or the destruction in a short period of time of a vast expanse of forest, as in the Amazon. The problem is that the most common situation for Indigenous peoples is the one described in this volume by Anguita Mariqueo (Chapter 12), where pressures over their territories and resources are more or less continuous, consistent with a wider logic of economic development, but not necessarily connected through a master plan 
promoted by states or corporations. In these circumstances Indigenous movements only have recourse to the more general norms about human rights, environmental sustainability and cultural diversity that, while recognized to some extent by the public and in official documents, are often ambiguous. Even when they are unambiguous, their enforcement by the state and other international institutions is faltering, to say the least. These circumstances often generate inward-directed violence and sometimes - as a strategy of last resort to seize the attention of the national and international public about impending environmental and social catastrophes - violent uprisings in the communities.

\section{Chapter Previews and Conclusions}

In the shifting terrain of rapidly changing structures of governance throughout the world today, the opportunities for alliances across social movements have become more numerous. Indigenous peoples further their life projects by engaging themselves with and against governments and corporate interests while connecting themselves into networks of exchange and solidarity with other groups and communities in their region, country or across the globe.

These movements have the potential, through these alliances, to disrupt emerging structures of governance, as several of the papers in this volume show. For example, Glenn McRae shows (Chapter 7) how the interaction between Vermonters and James Bay Crees, during the latter's campaign to stop a hydroelectric mega-development in Quebec, set in motion processes that led some Vermont activists to see their state in a new light and to undertake to transform the very structures through which Vermonters govern themselves. He shows that the forms of 'grassroots transnationalism' that emerge around this kind of campaign serve to stimulate and strengthen the communities that enter into contact, while they maintain their distinctiveness. These kinds of effects of Indigenous alliances have not been previously explored to our knowledge, and they expose the unexpected results and possibilities of Indigenous movements and alliances. Brian Craik (Chapter Io) looks at these connections from another perspective, that of the Crees' strategists and Cree leadership. He discusses the complex issues and decisions that the Cree leadership had to face, having to wage campaigns that responded, at the same time, to immediate opportunities, long-term goals, community demands, and allies' expectations. His is an insider's view into how some contemporary Indigenous organizations operate and forge connections that strengthen them while enhancing the autonomy of their allies.

The strengthening of connections and the transformation of networks is also a point addressed by Al Gedicks and Zoltán Grossman's chapter (I I) on 
the anti-mining coalition that emerged from a very unlikely terrain. In the I980s Indigenous and non-Indigenous communities in northern Wisconsin were often antagonistic to each other over the use of natural resources and treaty rights. Yet in the I99os the threat that mining operations posed to the same regional resources led these communities into unexpected alliances, which emerged not only from recognizing new common concerns, but from the utility of treaty and Native Americans' rights for protecting regional resources for all. As a result, the authors argue, the whole idea of who are outsiders and who are insiders has radically reshaped identities in ways that strengthen local and regional connections in the face of mobile capital. This resonates with Pramod Parajuli's chapter (I4) on the formation of 'ecological ethnicities'. Parajuli argues that the ravages of transnational capital itself produce the commonalities that connect ecological ethnicities across their differences: they are all dependent on the local resources from which mobile capital incessantly dispossesses them. As the Zapata- and Gandhi-inspired movements in Mexico and India show, in their struggles to sustain the basis of their livelihood and their ways of living, ecological ethnicities strive for a form of autonomy that alters relations of power and questions: 'what is power, what is governance and what are other possible roles of state, civil society and communities?'

Barbara Rose Johnston and Carmen Garcia-Downing (Chapter I3) discuss a different aspect of translocal connections. In their case, the connections under focus are those between a struggling Indigenous people, the Pehuenche of Chile, and human rights organizations, international professional associations, and development institutions. They show the possibilities and the limitations that these kinds of connections have for stopping human rights abuses in the context of mega-developments. Aldisson Anguita Mariqueo's chapter (i2) shows that, in the same national context, mega-developments are just part of a general historical and contemporary pattern of development that, because it proceeds through apparently unconnected operations, is not always recognized as a systematic abuse of Indigenous peoples' human rights.

Chief Matthew Coon Come describes (Chapter 9) a very similar pattern in a different national context, Canada. He forcefully argues that since colonial times, Canada and Quebec have consistently disregarded the Indigenous peoples' and his own James Bay Cree nation's interests and way of life as unworthy of attention when they dispose of land and resources in Cree territory. Thus he argues that the Crees not only seek to survive megadevelopments, they struggle to share equitably in the benefits of their lands, through their distinctive ways of life and ways of relating to the land, and he argues that this is founded on their determination to establish their rights of self-governance and self-determination. In her contribution (Chapter I 8), Dawn Martin-Hill provides an intimate and powerful portrayal of the human 
dimension of rights abuses. The testimonies she shares show the abusive exercises of power and the suffering they create, and how they are hidden by the abstract arguments of government and media. She shows what Lubicon Cree and particularly Lubicon women have to endure in the face of development, and yet how their struggles continue in the midst of their suffering.

Colin Scott argues in his chapter (I7) that in contemporary politics contested rights are at the core of structural reform vis-à-vis Aboriginal peoples. His chapter maps the contours of conflicting political discourses on Aboriginal entitlements and scrutinizes the assumptions that underlie policy prescriptions. He shows that these assumptions are rooted in long-standing European notions of civilization and progress, race, freedom and equality. He explores the effects of these notions on ideologies of state governance, property and market organization, and their impact on different options for Aboriginal self-determination and development.

For Peter Harries-Jones (Chapter I6), the ability to control their own forms of development is critical for Indigenous peoples' life-politics. He argues that the life-politics of Indigenous traditions counter a 'wild globalization' that is completely out of step with ecological cycles. He explores conceptual bridges that may both help science to understand and grapple with globalization in ecological terms, and establish connections between these scientific efforts and those that Indigenous peoples pursue through the traditional knowledge embodied in their life-politics. The connection between science and Indigenous traditional environmental knowledge, in the context of sustainable development, is the focus of Deborah McGregor's chapter (5). She shows that the ways TEK is conceptualized and used within dominant Western settings undermines its insights into the reasons for the environmental crisis, and its possible resolution. Turning from thinking of TEK as knowledge to exploring it as an ongoing way of living, she shows how TEK addresses power asymmetries between Indigenous and non-indigenous peoples. As long as this is unrecognized in TEK research and implementation, the uses of TEK in science and policymaking constitute another form of colonialism that cannot but reinforce the current crises of the environment.

The profound connections, from the standpoint of an Indigenous epistemology and ontology, that exist between the domination of one group of people by another and environmental degradation, are convincingly demonstrated by Mary Arquette, Maxine Cole and the Akwesasne Task Force on the Environment (ATFE). In Chapter I9 they show how the Haudenosaunee (Iroquois) conceive the whole of Creation as being a web of interconnections and responsibilities that cannot be interrupted without perilous consequences. Thus, the imposition of development and the disruption brought to the relations and responsibilities that the Mohawk of Akwesasne sustained with their 
environment have had devastating consequences for the whole of Creation. In order to reverse this process they propose that relations and responsibilities be given their proper respect. Harvey Feit's chapter (6) follows this line of argument by tracing the connections that many James Bay Crees see between ways of relating to non-humans and ways of relating to humans. In his analysis, Feit shifts the usual focus in studies of Indigenous peoples' relations to the environment by exploring how Cree ways of understanding relations to animals extend into the political actions of Cree leaders. In this way he interprets Crees' actions that, in the midst of struggles around development, appear to be in contradiction with their claims of attachment to the land, when in reality they are the most consummate example of this attachment.

In his statement (Chapter 3), Yshiro leader Bruno Barras aptly describes how governments, private interests and NGOs in Paraguay constantly make assumptions about the Yshiro's needs and thus carry on with their own agendas of development, always claiming that it is for the Yshiro's benefit. Against this the Yshiro counterpose their life projects, which are nothing less than being able to carry on with their own lives in a way that is meaningful and purposeful for them. For this, Barras says, the Yshiro need to be heard on their own, not through the voices of non-Indigenous NGOs or the government. In the following chapter (4), Mario Blaser discusses the context in which this plea for removing intermediaries makes sense. He shows how the idea of life projects took the form of a pan-Yshiro organization that is trying to regain for the Yshiro the authority to define themselves and their projects. Blaser shows that Indigenous peoples must engage with opponents and self-proclaimed allies, both of whom operate with dominant images of indigenousness that set the terms of debates about Yshiro futures. Thus, the Yshiro are compelled to cut across these debates in order to open up spaces for their own life projects.

Petra Rethmann focuses (Chapter IS) on a similar kind of attempt by Native activists in the Chukotka peninsula in the Russian Far East who search for ways to create political initiatives that are meaningful to the region's Indigenous peoples. She argues that these attempts involve the creation of 'fields of attraction' that are articulated in relation to several layers of history and against the grain of contemporary governmental and capitalist discourses of development in the region. Wendy Russell also discusses (Chapter 8) multiple layers of history that operate as a mnemonic tool to interrogate received notions of economic development for the Cree of Fort Albany in Canada. The memory of the people and history inscribed in the landscape of the settlement exposes the colonial policies that are the continuing context of present imbalances between this community and the mainstream industrial economy. The Cree discourses politicize the poverty 
of the community today and serve as keys in planning for self-sufficiency by building on the community's entrepreneurial traditions to restructure their relationships with regional economic, social and administrative networks.

As a consequence of their pursuits of these life projects, and almost as a side effect of them, we suggest that these kinds of Indigenous movements imply a reshaping of current structures of governance. These chapters highlight the question and the possibilities: might Indigenous peoples, and other counter-hegemonic movements, generate alternatives to the structures of governance furthered by development under its new guise as globalization?

\section{Notes}

I. By 'governance' we refer to the complex of practices, discourses and institutions by means of which human populations and the processes of 'nature' are conducted according to certain ends that themselves are informed by specific values and visions of the world.

2. For the antecedents of the environmental movement, see Grove I995, Judd 2000, and Guha and Martinez-Alier 1997. For details of the consolidation of the environmental movement in the I980s, see Keck and Sikkink I998.

3. We take the phrase from the title of an article by Peter Brosius 1997 on environmentalists' representations of Indigenous knowledge.

4. Some sources in English focusing on different national contexts are Albó I999; Maybury-Lewis 1999; Van Cott 1994; Diaz Polanco 1997; Warren 1998; Warren and Jackson 2002; Ramos 1998; Gutierrez 1999; Assies et al. 2000; Niezen 2003; Alfred 1999; RCAP 1996; Bellier and Legros 200I. The literature trying to provide a coherent picture of the transnational dimension of Indigenous movements is still scarce. For the most relevant examples see Wilmer 1993, Brysk 2000, and Niezen 2003.

5. By a relatively independent judicial system we mean not only that interference and intrusion by other state institutions in the judicial process is limited but also that even in cases where this is the case, the judicial system itself responds to culturally specific understandings of justice. Thus, it can never be impartial and independent in relation to Indigenous conceptions of justice.

6. The 'boomerang strategy' consists in Indigenous peoples allying themselves with other interested parties (most often environmental and human rights movements) who can reach and lobby external financing institutions or governments so that these exert pressures on national governments.

7. By 'norms' we mean values that are usually codified as laws, covenants, policy frameworks, operational directives, etc.

\section{References}

Adams, W.M. (I995) 'Green development theory? Environmentalism and sustainable development', in J. Crush (ed.), Power of Development, London: Routledge, pp. 87-99.

Albó, X. (I999) 'Andean people in the twentieth century', in F. Salomon and S. Schwartz (eds), The Cambridge History of the Native Peoples of the Americas, vol. 3: South America - Part 2, Cambridge: Cambridge University Press, pp. 765-869. 
Alfred,T. (1999) Peace, Power, Righteousness: An Indigenous Manifesto, Oxford: Oxford University Press

Alvarez, S.E., E. Dagnino and A. Escobar (eds) (1998) Cultures of Politics Politics of Cultures: Re-visioning Latin American Social Movements, Boulder, CO: Westview Press.

Asch, M. (1984) Home and Native Land: Aboriginal Rights and the Canadian Constitution, Toronto: Methuen.

- (1997) Aboriginal and Treaty Rights in Canada, Vancouver: UBC Press.

(2000) 'First Nations and the derivation of Canada's underlying title: comparing perspectives on legal ideology', in C. Cook and J. Lindau (eds), Aboriginal Rights and Self-Government: The Canadian and Mexican Experience in North American Perspective, Montreal: McGill-Queen's University Press, pp. 148-67.

Assies, W. G. van der Haar, and A. Hoekema (eds) (2000) The Challenge of Diversity: Indigenous Peoples and Reform of the State in Latin America, Amsterdam: Thela Thesis.

Barry, A., T. Osborne and N. Rose (eds) (1996) Foncault and Political Reason: Liberalism, Neo-Liberalism and Rationalities of Government, Chicago: University of Chicago Press.

Bellier, Irene and Dominique Legros (eds) (200I) 'Mondialisation et stratégies politiques autochtones', Recherches amérindiennes au Québec, vol. 3 I, no. 3.

Bodley, J.H. (1988) Tribal Peoples and Development Issues: A Global Overview, Mountain View, CA: Mayfield.

Brosius, J.P. (1997) 'Endangered forest, endangered people: environmentalist representations of Indigenous knowledge', Human Ecology, vol. 25, no. 1, pp. 47-69.

Brysk, A. (1994) 'Acting globally: Indian rights and international politics in Latin America', in D. Van Cott (ed.), Indigenous Peoples and Democracy in Latin America, New York: St Martin's Press, pp. 29-51.

_ (1996) 'Turning weakness into strength: the internationalization of Indian rights', Latin American Perspectives, vol. 23, no. 2, pp. 38-57.

- (2000) From Tribal Village to Global Village: Indian Rights and International Relations in Latin America, Stanford: Stanford University Press.

Burger, J. (I998) 'Indigenous peoples and the United Nations', in Cohen C. Price (ed.), The Human Rights of Indigenous Peoples, Ardsley, FL: Transnational, pp. 3-16.

Collinson, H. (ed.) (I997) Green Guerrillas: Environmental Conflicts and Initiatives in Latin America and the Caribbean, Montreal: Black Rose Books.

Conklin, B.A. (I997) 'Body paint, feathers, and VCRs: aesthetics and authenticity in Amazonian activism', American Ethnologist, vol. 24, no. 4, pp. 71 I-37.

- and L.R. Grahan (I995) 'The shifting middle ground: Amazonian Indians and eco-politics', American Anthropologist, vol. 97, no. 4, pp. 695-710.

Davis, S.H. (1977) Victims of the Mirade: Development and the Indians of Brazil, Cambridge: Cambridge University Press.

- (I993) 'The World Bank and Indigenous peoples', Washington, DC: World Bank, at www.worldbank.org/html/extdr/thematic.htm (and choose Indigenous Peoples and then Resources).

Deruyttere, A. (1997) El Banco Interamericano de Desarrollo y los pueblos indigenas, Documento de Trabajo: Unidad de Pueblos Indígenas y Desarrollo Comunitario, Washington, DC: Banco Interamericano de Desarrollo, Departamento de Desarrollo Sostenible.

Diaz Polanco, H. (I g97) Indigenous Peoples in Latin America: The Quest for Self-Determination, Boulder, CO: Westview Press.

Eade, D. (ed.) (2000) Development, NGOs and Civil Society: A Development in Practice Reader, Oxford: Oxfam.

Edwards, M. and D. Hulme (1996a) Beyond the Magic Bullet: NGO Performance and Accountability in the Post-Cold War World, West Hartford, CT: Kumarian Press. 
(1996b) 'Too close for comfort: the impact of official aid on nongovernmental organizations', World Development, vol. 24, no. 6, pp. 96I-73.

Ekins, P. (1993) 'Making development sustainable', in W. Sachs (ed.), Global Ecology: A New Arena of Political Conflict, London: Zed Books, pp. 91-103.

Ellen, R. and H. Harris (2000) 'Introduction', in R. Ellen, P. Parkes and A. Bicker (eds), Indigenous Environmental Knouledge and Its Transformations, Amsterdam: Hardwood, pp. I-33.

Esteva, G. and M. Prakash (1998) Grassroots Post-modemism: Remaking the Soil of Cultures, London: Zed Books.

Fisher, W. (1997) 'Doing good? The politics and antipolitics of NGO practices', Annual Revieu of Anthropology 26, pp. 439-64.

Fox, J. and David Brown (eds) (I998) The Struggle for Accountability: The World Bank, NGOs, and Grassroots Movenents, Cambridge, MA: MIT Press.

Geddicks, A. (1993) The New Resource Wars. Boston: South End Press.

Grove, R.H. (I995) Green Imperialism: Colonial Expansion, Tropical Island Edens and the Origin of Environmentalism, 1600-1860, Cambridge: Cambridge University Press.

Guha, R. and J. Martinez-Alier (1997) Varieties of Environmentalism: Essays North and South, London: Earthscan.

Gutierrez, N. (I999) Nationalist Myths and Ethnic Identities: Indigenous Intellectuals and the Mexican State, Lincoln: University of Nebraska Press.

Hajer, M. (1995) The Politics of Environmental Discourse: Ecological Modernization and the Policy Process, Oxford: Oxford University Press.

Harring, Sidney L. (2002) 'Indian law, sovereignty, and state law: native people and the law', in Philip L. Deloria and Neal Salisbury (eds), A Companion to American Indian History, Oxford: Blackwell, pp. 441-59.

Horst, Rene (1998) 'Authoritarianism, Indigenous resistance and religious missions: Paraguay, I958-1992', Ph.D. thesis, Department of History, Indiana University.

Hudock, A. (1999) NGOs and Civil Society: Democracy by Proxy? Cambridge: Polity Press.

Hulme, D. and M. Edwards (eds) (I997) NGOs, States and Donors: Too Close for Confort? New York: St Martin's Press.

International Labour Organization (ILO) (I957) Intemational Labour Organization Convention (no. 107) concerning the Protection and Integration of Indigenous and Other Tribal and SemiTribal Populations in Independent Countries, New York: United Nations Treaty Series.

Judd, R. (2000) Common Lands, Common People: The Origins of Conservation in Northern Neu England, Cambridge, MA: Harvard University Press.

Keck, M. and K. Sikkink (1998) Activists beyond Borders: Advocacy Networks in International Politics, Ithaca: Cornell University Press.

Kreimer, O. (1998) 'The future inter-American declaration on the rights of Indigenous peoples: a challenge for the Americas', in Cohen C. Price (ed.), The Human Rights of Indigenous Peoples, Ardsley, FL: Transnational, pp. 63-72.

Lanthier, I. and L. Olivier (1999) "The construction of environmental "awareness", in E. Darier (ed.), Discourses of the Environment, Oxford: Blackwell, pp. 63-78.

Lyons, Oren and John Mohawk (eds) (1992) Exiled in the Land of the Free: Democracy, Indian Nations, and the U.S. Constitution, Santa Fe: Clear Light.

Martinez Cobo, J. (1986) Study of the Problem of Discrimination against Indigenous Populations, New York: United Nations.

Maybury-Lewis, D. (1999) 'Lowland peoples of the twentieth century', in F. Salomon and S. Schwartz (eds), The Cambridge History of the Native Peoples of the Americas, vol. 3: South America - Part 2, Cambridge: Cambridge University Press, pp. 872-938. 
Messer, E. (1993) 'Anthropology and human rights', Annual Review of Anthropology, vol. 22 , no. $221-49$.

Niezen, R. (2003) The Origins of Indigenism: Human Rights and the Politics of Identity, Berkeley: University of California Press.

Painter, M. and W.H. Durham (eds) (1995) The Social Causes of Environmental Destruction in Latin America, Ann Arbor: University of Michigan Press.

Parajuli, P. (I998) 'Beyond capitalized nature: ecological ethnicity as an arena of conflict in the regime of globalization', Eamene, vol. 5, no. 2, pp. I86-217.

Pearce, J. (1997) 'Between co-option and irrelevance? Latin American NGOs in the Igyos', in D. Hulme and M. Edwards (eds), NGOs, States and Donors: Too Close for Comfort? New York: St Martin's Press, pp. 257-74.

Peet, R. and M. Watts (1996) 'Liberation ecology: development, sustainability, and environment in an age of market triumphalism', in M. Watts and R. Peet (eds), Liberation Ecologies: Environment, Development Social Movements, London: Routledge, pp. 1-45.

Povinelli, Elizabeth A. (1994) Labor's Lot: The Pouer, History, and Culture of Aboriginal Action, Chicago: University of Chicago Press.

- (2002) The Cunning of Recognition, Durham, NC: Duke University Press.

Ramos, A.R. (1998) Indigenism: Ethnic Politics in Brazil, Madison: University of Wisconsin Press.

Rist, G. (1997) The History of Development: From Western Origins to Global Faith, London: Zed Books.

Rose, N. (I996) 'Governing "advanced" liberal democracies', in A. Barry, T. Osborne and N. Rose (eds), Foucault and Political Reason: Liberalism, Neo-Liberalism and Rationalities of Government, Chicago: University of Chicago Press, pp. 37-64.

RCAP (Royal Commission on Aboriginal Peoples) (1996) Report of the Royal Commission on Aboriginal Peoples, 5 vols., Ottawa: Royal Commission on Aboriginal Peoples. Also on CD-ROM (I997) For Seven Generations, Ottawa: Libraxus.

Sanders, D. (1973) 'Native people in areas of internal national expansion: Indians and Inuit in Canada', IWGIA Document 14.

- (1977) 'The formation of the World Council of Indigenous Peoples', IWGIA Document 29.

- (1998) 'The legacy of Deskaheh: Indigenous peoples as international actors', in Cohen C. Price (ed.), The Human Rights of Indigenous Peoples, Ardsley, FL: Transnational, pp. $73-88$.

Sieder, R. (ed.) (2002) Multiculturalism in Latin America: Indigenous Rights, Diversity and Democracy, New York: Palgrave Macmillan.

Stavenhagen, R. (I996) 'Indigenous rights: some conceptual problems', in E. Jelin and E. Hershberg (eds), Constructing Democracy: Human Rights, Citizenship, and Society in Latin America, Boulder, CO: Westview Press, pp. I $4 \mathrm{I}^{-59}$.

Swepston, L. (1998) 'The Indigenous and tribal peoples convention (no. r69): Eight years after adoption', in Cohen C. Price (ed.), The Human Rights of Indigenous Peoples, Ardsley, FL: Transnational, pp. 17-36.

Taylor, B. (ed.) (I995) Ecological Resistance Movements: The Global Emergence of Radical and Popular Environmentalism, Buffalo: SUNY Press.

Tomasevski, K. (1993) Development Aid and Human Rights Revisited, New York: Pinter.

Tully, James (1995) Strange Multiplicity. Constitutionalism in an Age of Diversity, Cambridge:

Cambridge University Press.
$-(2000)$ 'A just relationship between Aboriginal and non-Aboriginal peoples of Canada', in C. Cook and J. Lindau (eds), Aboriginal Rights and Self-Government: The 
Canadian and Mexican Experience in North American Perspective, Montreal: McGill-Queen's University Press, pp. 39-7 I.

UNCED (United Nations Conference on Environment and Development) (1992) Agenda 21: Programme of Action for Sustainable Development - Rio Declaration on Environment and Development - Statement of Forest Principles - the Final Text of Agreements ... United Nations Conference on Environment and Development, New York: United Nations Department of Public Information.

UNDP (United Nations Development Programme) (I990) Human Development Report, Oxford: Oxford University Press.

Van Cott, D. (2000) The Friendly Liquidation of the Past: The Politics of Diversity in Latin America, Pittsburgh: University of Pittsburgh Press.

(ed.) (r994) Indigenous Peoples and Democracy in Latin America, New York: St Martin's Press.

Warren, Kay B. (1998) Indigenous Moventents and Their Crifics: Pan-Maya Activism in Guatemala, Princeton: Princeton University Press.

- and J. Jackson (eds) (2002) Indigenous Movements, Self-Representation and the State in Latin America, Austin: University of Texas Press.

WCED (World Commission on Environment and Development) (1987) Our Common Future, Oxford: Oxford University Press.

Wilmer, F. (I993) The Indigenous Voice in World Politics, Newbury Park, CA: Sage Publications.

Wood, G. (I997) 'States without citizens: the problem of the franchise state', in D. Hulme and M. Edwards (eds), NGOs, States and Donors: Too Close for Comfort? New York: St Martin's Press, pp. $79-92$.

Worster, D. (I 993) 'The shaky ground of sustainability', in W. Sachs (ed.), Global Ecology: A New Arena of Political Confiat, London: Zed Books, pp. 132-45.

Wright, R.M. (I988) 'Anthropological presuppositions of Indigenous advocacy', Anmual Revicu of Anthropology 17, pp. 365-90.

Yashar, D. (1998) 'Indigenous movements and democracy in Latin America', Comparative Politics, vol. 3 I, no. I, pp. 23-43. 


\title{
In the Way of Development
}

\section{Indigenous Peoples, Life Projects and Globalization}

\author{
EDITED BY MARIO BLASER, \\ HARVEY A. FEIT AND GLENN MCRAE
}

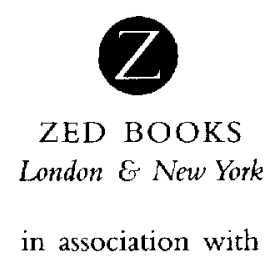

International Development Research Centre

Ottawa Cairo $\cdot$ Dakar $\cdot$ Montevideo $\cdot$ Nairobi $\cdot$ New Delhi $\cdot$ Singapore 
In the Way of Development was first published in 2004 by

Zed Books Ltd, 7 Cynthia Street, London NI 9JF, UK, and Room 400, I75 Fifth Avenue, New York, NY IOoIo, USA

in association with the International Development Research Centre, Box 8500 , Ottawa on, Canada kig 3 H9 info@idrc.ca/www.idrc.ca

www.zedbooks.co.uk

Editorial copyright (C) Mario Blaser, Harvey A. Feit and Glenn McRae, 2004 Copyright $\mathbb{C}$ individual contributors

The right of the contributors to be identified as the authors of this work have been asserted by them in accordance with the Copyright, Designs and Patents Act, 1988

Designed and typeset in Monotype Bembo by Illuminati, Grosmont Cover designed by Andrew Corbett Printed and bound by Gutenberg Press, Malta

Distributed in the USA exclusively by Palgrave Macmillan, a division of St Martin's Press, LLC, I75 Fifth Avenue, New York, NY 10010

All rights reserved

A catalogue record for this book is available from the British Library

Library of Congress Cataloging-in-Publication Data available

Zed ISBN I 84277 I92 2 (Hb)

Zed ISBN I 84277193 o (Pb)

IDRC ISBN I 552500047 